\section{Legislative Update - September, 2000}

\author{
Allison Weber Shuren, NP, JD
}

\section{SPECIALITY DESIGNATIONFOR INTERVENTIONAL PAINMANAGEMENT}

The Medicare Physician fee Schedule does not reflect accurately the costs of providing interventional pain management services to Medicare beneficiaries. The practice expense for pain management services are not based on the resources used by interventional pain physicians, but rather, are determined on the practice expenses incurred by the specialities from which the subspecialty derived - principally general anesthesia, which is the lowest practice expense per hour of any medical specialty. In many cases, consequently, the rate of payment does not cover the costs of providing these services.

Recognizing that American Society of Interventional Pain Physicians members and other interventional pain physicians cannot continue to bear the tremendous uncompensated costs associated with providing these services to Medicare beneficiaries, ASIPP through its Washington representatives, is calling upon Congress for assistance. ASIPP is asking for Congress to pass legislation directing the Secretary of Health and Human Services to establish a separate speciality designation for interventional al pain physicians so that a separate practice expense may be established based on the resources used to deliver the services required. Prior to reaching out to legislators, ASIPP attempted to resolve this issue with the Health Care Financing Administration; however, the Agency stated thatit was not interested in developing a new speciality designation. ASIPP's Washington team has already secured letters from Representatives Whitfield (R-Ky) and Pallone (D-NJ) urging their colleagues to address the designation issue before the 106th Congress session ends.

From Arent Fox Klintner Plotkin \& Kahn, PLLC, Washington, D.C. Ms. Shuren is an attorney at Arent Fox and Counsel for American Society of Interventional Pain Physicians. Address correspondence: Allison Weber Shuren, Esq., 1050 Connecticut Avenue NW, Washington, D.C. 20036

\section{ASCPROGRAMTRANSMITTAL}

ASIPP and its Washington representatives continue to visit Congressional offices in the hopes of restoring the remaining 2000 CPT codes excluded from HCFA's April 2000 Program Memorandum for pain management procedures provided in ambulatory surgical centers. The remaining services that have not received replacement codes are: 62262, 64479, 64480, 64483, 64484, 64470, 64472, 64626, and 64627.

Senator Mitch McConnell (R-KY) and Congressmen Ron Lewis (R-KY), Ed Whitfield (R-KY), and Frank Pallone(DNJ) have contacted HCFA by letter on behalf of ASIPP requesting the addition of the above listed codes. HCFA responded to Senator McConnell on July 21 stating that "the additional codes.... were not crosswalked by CPT," and therefore, "must go through the Federal Register notice with public comment." Senator McConnell's office has been supplied with a draft response to HCFA, requesting further guidance from the Agency as to the relevance of the CPT cross-reference, particularly since the codes at issue appear with statistics in the HCFA 1998 utilization data posted on the Agency's website. The statistics indicate that HCFA must have cross-referenced the codes at issue to pre-existing codes, clearly indicating that crosswalks exist for them. ASIPP and its Washington representatives, have contacted HCFA directly on this matter and are awaiting a response from the agency. In the meantime, work continues with Senator McConnell's office as he reviews the draft letter.

This issue is an important issue to be discussed on Capitol Hill by ASIPP members participating in Congressional meetings on September 18 as part of the organization's annual meeting in Washington, D.C.

\section{HOSPITAL OUTPATIENT FINAL RULE IMPLEMENTED}

Despite repeated and ardent requests of several hospital organizations urging further delay of the implementation of the hospital outpatient final rule, the new prospective 
payment system became effective on August 1, 2000. Although a contingency plan was prepared in case Medicare providers and intermediaries experienced problems in the transition, HCFA opted not to invoke further delay of the hospital outpatient PPS. Some glitches have arisen, and HCFA claims that although some problems may not be fixed until January 2001, that the majority will be resolved by October.

Hospitals have expressed their concerns with the PPS implementation, including the fear of possible investigations for fraud if overpayments are received due to new system errors. HCFA contends that some problems should be expected, but that implementation problems will be remembered when reviewing submissions.

\section{PATIENT'S BILL OF RIGHTS}

Congress entered into the August recess without completing conference action on the House and Senate bills addressing a patient's bill of rights. The House bill, H.R. 2990 , is very comprehensive, covering all privately insured Americans and includes additional legal remedies for patients and their families. The Senate version, S. 1344, would apply only to those with plans governed by the Employee Retirement Income Security Act (ERISA), and does not enlarge health plan liability.

Supporters of H.R. 2990 are hopeful that the presence of an additional Democratic Senator will increase their chances of enacting House language. Senator Zell Miller (D-GA) was appointed by Georgia's Governor to fill the Senate seat vacated by the late Paul Coverdell. This extra Democratic vote may be key to passing or causing a tie-breaker on a conference bill mirroring House provisions.

Senator Don Nickles (R-OK), conference chair of the managed care bills, offered an amendment to the Labor, Health and Human Services and Education appropriations bill for fiscal year 2001, which would allow an expanded right to sue in federal court under certain limitations. Although adopted, this measure is not expected to be included in the final conference report.

While Congress is expected to deal with this issue in early September, it is important to note that Congress may address a revised version of the Norwood/Dingell bill rather than the House version currently in conference.

\section{REPROCESSING OF SINGLE-USEDEVICES}

On August 2, 2000, the U.S. Food and Drug Administration (FDA) issued final guidance on the reuse of medical devices marketed for single-use. The final guidance entitled, "Enforcement Priorities for Single-Use Devices Reprocessed by Third Parties and Hospitals," largely mirrors the requirements in the proposed guidance and sets forth the Agency's enforcement priorities regarding the reprocessing of medical devices.

Before the issuance of the guidance, the FDA limited its enforcement efforts to reprocessing of single-use devices done by original manufacturers which permitted the proliferation of a "reprocessing industry" by non-manufacturers that functioned essentially with no oversight. The alarming growth of reprocessing, coupled with the marginal data available documenting the affect of reprocessing on many devices, intensified public safety and ethical concerns and pushed Congress to pressure the FDA to address the enforcement gap.

Under the guidance, the FDA expects third-party processors and hospitals that engage in reprocessing to meet the same regulatory requirements as original manufacturers. Thus, these entities must comply with the following: premarket notification and approval requirements, registrations and listing of firms, submissions of adverse event reports, manufacturing and labeling requirements, medical device tracking, and establishment of system to correct or remove unsafe devices from the market. FDA's pre-market submission requirements will be based on the existing medical device classification system. The agency made clear, however, that it will phase in its enforcement of the pre-market submission requirements by device class. Hospitals and third-party reprocessors are expected to be inline with the regulations for class III, high-risk devices, within six (6) months; class II, moderate-risk, non-exempt devices, within twelve (12) months; and class I, low-risk, non-exempt devices, within eighteen (18) months. The FDA intends to consider, on a case-by-case basis, whether non-exempt status of a device should be revoked based on reprocessing issues.

The Agency also will phase-in enforcement of other existing non pre-market requirements for hospitals over a year period. The complete guidance document may found on the FDA web site at www.fda.gov/cdrh/comp/guidance/ 1168.pdf. 


\section{MEDICALERRORS}

The Labor, Health and Human Services and Education draft conference report for fiscal year 2001 includes a $\$ 50$ million appropriation for the establishment of a national center for patient safety within the Agency for Healthcare Research and Quality (AHRQ). This center was recommended in the Institute of Medicine's 1999 report, "To Err is Human", and was offered \$20 million under the President's budget. This center will be responsible for conducting research on improving safety and health care quality. Although the Labor HHS conference report has not yet been signed by the House and Senate for review by the Administration, it is expected to move forward when Congress returns from August recess.

\section{PHYSICIANCOLLECTIVEBARGAINING}

After five hours of debate, H.R. 1304, the Quality HealthCare Coalition Act, passed the House of Representatives on June 30 by a vote of 225-197 with divided Republican support. This bill would grant exception for federal antitrust laws to independent, self-employed physicians allowing them to organize for the purposes of bargaining collectively with health plans.

Although the bill has been referred to the Senate, no companion measure has yet been introduced, and Majority Leader Trent Lott has openly expressed his opposition to the bill fearing that it will encourage more lawsuits in an already active litigious society. In addition, the Clinton Administration has not issued a statement on this legislation, but two of the Administration's agencies have spoken out in opposition, the Federal Trade Commission and the Department of Justice.

Opponents of the bill include non-physician health care provider groups, insurers and some business groups, who argue that H.R. 1304 will allow doctors to force health plans to accept terms that can disadvantage non-physician providers and raise health care costs. A report issued by the American Association of Health Plans estimated that health care costs would increase by $8.6 \%$ if H.R. 1304 is enacted into law.

ASIPP contacted Congressman Ed Whitfield (R-KY) about this bill and was informed that he supported H.R. 1304 during House consideration. However, Senator Lott (R-MS) is unlikely to promote the bill on the Senate floor.

\section{MEDICAREPHYSICIANFEESCHEDULE PROPOSED RULE FOR 2001}

On July 17, 2000 the Health Care Financing Administration published the Notice of Proposed Rulemaking for the year 2001 Medicare Physician Fee Schedule in the Federal Register. The 2001 fee schedule represents the third year in the four year transition to a completely resource-based system for establishing the relative value units (RVUs) for procedures and services billed to the Medicare Part B program by physicians and other providers. The proposal focuses on the continued refinement of the resource-based practice expense methodology, changes to the geographic practice indices (GPCIs), and changes to the resource-based malpractice RVU established last year.

ASIPP intends to submit comments to HCFA Administrator Min DeParle regarding the significant underpayment of many of the procedures critical to interventional pain physicians. Comments regarding the rule will be accepted until September 15, 2000.

\section{MATTERS UNDER CONSIDERATIONBYTHE AMERICANMEDICAL ASSOCIATION HOUSE OF DELEGATES}

In May of this year, the Society of Cardiovascular and Interventional Radiology introduced a resolution to the American Medical Association House of Delegates expressing support for component coding. The resolution explains that the CPT system provides for "interchangeable component codes which allow physicians to more accurately describe their services in a "building-block" manner." Yet despite the benefit of improved description of services rendered, some payers, such as Medicare, fail to consistently apply the system of component coding. To address this problem, the resolution calls on the AMA to develop educational materials, which would outline the appropriate use of CPT codes for use by payers. The resolution requires the AMA to report back to the Delegates at the 2000 Interim Meeting regarding this issue.

Also, the Ohio Delegation offered a resolution denouncing the automatic E/M downcoding or recoding by managed care as fraudulent, and "is seeking relief from the Ohio Department of Insurance, the Ohio Attorney General, and any other appropriate organizations such that the practice of automatic downcoding or recoding by a managed care organization be deemed not only inappropriate, but fraudulent." The Resolution asks the AMA to amend AMA Policy H-70.937 by adding "recoding" where appropriate. 


\section{ANESTHESIOLOGIST'S REVOCATIONOF MEDICAL PRIVILEGES}

A anesthesiologist who lost his medical staff privileges at a Virginia hospital for alleged malpractice although the hospital peer review committee concluded he had met the requisite standard of care won the right on appeal to bring several claims against the institution and three of its medical staff members. In 1998, the anesthesiologist filed six claims against the Shenandoah Memorial Hospital (SMH), all of which were dismissed by the district court. The six allegations against SMH included: breach of medical staff bylaws, breach of oral contract, civil conspiracy, common law conspiracy to breach contractual obligations, common law defamation, and tortious interference.

According to reports, in addition to his claims regarding the unfounded malpractice claims and inappropriate revocation of his privilege, the physician alleged that another anesthesiologist on staff disparaged him to the hospital and other colleagues in order to secure work for himself and that he was told not to work full-time despite his oneyear full-time contract. The U.S. Court of Appeals for the Fourth Circuit agreed that the hospital had breached its bylaws and held that while a principal cannot conspire with an agent, a civil conspiracy may be invoked "when officers or agents have "independent personal stakes" in achieving the illegal end." BNA, Health Law Reporter, Vol. 9, No. 30 (July 27, 2000) (citing Wuchenich v. Shenandoah Memorial Hospital, 4th Cir., No. 99-1273, 5/22/00 (unpublished opinion)). Since the defendant's reputation was at stake and his ability to practice was threatened due to the facility's unwillingness to allot a reasonable number of patients, the conspiracy claim was partially reversed.

\section{NEWOVERPAYMENT/UNDERPAYMENT INTERESTRATE}

With the passing of the HCFA September 1 deadline for providers to submit applications for transitional passthrough or new technology status for items or services paid for under Medicare's hospital outpatient department prospective payment system and provided on or after January 1,2000 , the Agency will now work on quarterly cycles. The filing deadline for each update will be first day of the quarter immediately prior to the quarter for which the filing is related.

In addition, effective August 1, HCFA instituted a new interest rate for health care providers that are overpaid or underpaid in their Medicare claims from HCFA. The over- payment/underpayment interest rate, which is based upon the higher of the private consumer rate or the current value of funds rate, has been increased to $13.875 \%$ from $13.75 \%$ to reflect an increase in the private consumer rate.

\section{FINALSTANDARDSFORELECTRONIC TRANSFERS ISSUED BY HHS}

In August, the Department of Health and Human Services issued the final standards for electronic transfers as required by the Health Insurance Portability and Accountability Act (HIPAA). This standard is expected to provide uniformity and to streamline the electronic transfer process allowing providers to spend less time on paperwork and more time with patients. Health plans, certain providers and healthcare clearinghouses are required to have the new standards implemented in two years, with smaller health plans being granted an additional year. The final standards maybe found at: www.access.gpo.gov/ su_docs/fedreg/a000817c.html.

\section{JCAHO STANDARDS OF PAIN MANAGEMENT}

It was recently reported that pain management standards established the Joint Commission on Accreditation of Healthcare Organizations (JCAHO) in August of 1999 have received a ninety-two (92) percent approval rating by providers, consumers, and health plans. The six chapters, which are listed below, were released to bring awareness of the issue of pain management and improve the quality of pain management provided patients. The chapters are:

- recognizing the right of individuals to appropriate assessment and management of pain; assessing the existence and, if so, the nature and intensity of pain in all patients, resident, or clients;

- establishing policies and procedures that support the appropriate prescribing or ordering of effective pain medications; educating patients, residents, and clients and families about effective pain management; addressing an individual's needs for symptom management in the discharge planning process; and incorporating pain management into the organization's performance measurement and improvement program. 


\section{ALL-PRODUCTS CLAUSE DROPPED IN CONNECTICUT}

In May of this year, Aetna CEO William H. Donaldson announced the company's intent to remove the all-products clause for the one/sixth of physicians in the state of Connecticut who are not based in hospitals. Although at present this is not occurring in other states, Mr. Donaldson also remarked that Aetna would work to make "improvements in other markets." Some physicians are skeptical about Aetna's promise and are waiting for actual implementation.

\section{KENTUCKY HB 371 BANS "ALL PRODUCTS CLAUSES"}

Kentucky General Assembly in its 2000 legislation adopted HB 371 banning "all products clauses." HB 371 declares that it is unfair trade practie for an insurer that offers multiple health benefit plans to require a health care provider, as a condition of praticipating in a health plan of the insurer, to praticipate in any of the insurer's other health benefit plans.

\section{BILL TO OPEN NATIONAL PRACTITIONER DATA BANK TO PUBLIC}

At press time, House Commerce Committee Chairman Thomas Bliley had announced his plan to introduce a bill that would open the information stored in the National Practitioner Data Bank (NPDB) to the public. While the content of the bill is unknown, it is hopeful that the Chairman's draft will address concerns raised by some of his fellow committee members about permitting the public access of the information in its current format. ASIPP will be monitoring the bill closely.

\section{ASC FINAL RULE STATUS}

According to HCFA officials, agency personnel are working diligently to complete the ambulatory surgery center (ASC) APC final rule by the end of November 2000. If the final rule is actually completed and published in November, implementation will be scheduled for sometime in April 2001.

If the final rule is published this fall, the APC system will be implemented over a three-year phase-in. This is because the 1999 Balance Budget Act refinement bill requires the agency to incorporate data from its 1999 Medicare ASC survey into the forthcoming rule, or else phase-in the APC rates based on the old data. The phase-in would be over a period of at least three years.

It is believed, however, that the 1999 Medicare ASC survey, which is required by statute, is still not yet underway. This is because the Office of Management and Budget (OMB) has not yet given its necessary approval of the survey to be used by ASCs. Indeed, according to HCFA personnel, the survey form has been sitting with OMB for quite some time, and HCFA has not been given any estimate from OMB as to a review completion date. Thus, if HCFA is committed to a November deadline, the agency will not have survey data on which to rely. HCFA therefore will have to implement the APCs via phase-in.

\section{STARK II REGULATIONSPENDING}

HCFA officials have again revised their estimated completion date for the final regulations implementing the federal physician self-referral prohibition statute (the "Stark Law"). The latest information from HCFA is that the final Stark Law rule will be issued by the end of September. HCFA officials have stated that the rule is nearly finished, and that although work on the rule is not yet complete, it is hopeful OMB will expedite its review of the final regulation. Thus, in contrast to many other pending regulations, publication of the Stark final rule will occur shortly after HCFA's work is complete. Early indications are that the agency may provide for additional comment as well as delayed implementation.

In addition, Rep. Bill Thomas (R-CA) has revived his push for legislation that would dramatically curtail the Stark Law coverage and prohibitions. Congressional staffers have indicated that such a bill's best chances are as an add-on to a Medicare BBA "give-back" bill.

\section{0-DAY BAN ON OFFICE-BASED SURGERIES IN FLORIDA}

After receiving reports of twenty adverse events and five patient deaths involving elective, in-office surgical procedures (mainly cosmetic in nature), the Florida Board of Medicine imposed a 90-day moratorium on procedures requiring general anesthesia, certain levels of intravenous sedation and major conduction anesthesia. Most of the procedures are classified as level III surgeries under state rules. The Board appears to have concluded that inadequate anesthesia monitoring and extended operating time due to multiple procedures being done at one time are the at the core of the bad outcomes. Reports suggest that the 
discussions with Florida physician may lead to a narrowing of the ban.

\section{PAINRELIEF PROMOTIONACT}

The Pain Relief Promotion Act, S. 1272, likely will come up for a vote before Congress adjourns for the year. S. 1272 is the companion measure to H.R. 2260, which passed the House of Representatives on October 27, 1999. This bill would invalidate Oregon's assisted suicide law by banning the use of federally regulated drugs for assisted suicides and preventing the U.S. Attorney General from recognizing any state law that permits assisted suicide or euthanasia.

The legislation also amends the Controlled Substances Act to provide that alleviating pain or discomfort in the usual course of professional practice is a legitimate medi- cal purpose for the dispensing of a controlled substance that is consistent with public health and safety, even if the use of such a substance may increase the risk of death. Moreover, the bill mandates and pays for training programs in pain management at the local, state and federal level.

In order to provide an opportunity for fair debate, S. 1272 will probably be subject to a cloture vote, which is a legislative term signifying that debate should come to an end and that a vote on final passage should occur. Less controversial bills may be passed by unanimous consent, meaning that problem matters have been worked out behind the scenes and that a bill can be voted on without further debate. Although Senator Nickles is confident that there are enough votes to secure passage, invoking cloture may present a problem because it requires the approval of sixty Members, rather than a percentage of those present and voting. 